\title{
Host Plant Resistance to Fusarium Tuber Rot in Commercial Caladium Cultivars 1
}

Z. Deng, N.A. Peres, and B.K. Harbaugh ${ }^{2}$

\section{Introduction}

\section{Caladiums (Caladium x hortulanum) are} ornamental aroids widely used in landscapes, especially in the southern United States, and in production of pot plants worldwide. The production of tubers is primarily through propagating pieces of "seed" tubers. Tuber quality is therefore critical for field production of tubers as well as for whole tubers used for landscaping or for production of potted plants in the greenhouse. Fusarium tuber rot, caused by Fusarium solani, has been the most destructive disease affecting caladium tuber quality and quantity (Knauss, 1975). Over the last decade, this disease has caused a steady decline in tuber yield of many cultivars in Florida and has led in part to the elimination of a number of commercial cultivars (McGovern, 2004). Chemical control of this disease using fungicides has had limited success. Tissue culture has been used to eliminate Fusarium from "seed" tubers, resulting in an increase in tuber yield and quality and plant performance, but these beneficial effects may be lost within several years because of natural re-infection when the tissue-culture-derived seed pieces are planted in the field. Identification and utilization of host plant disease resistance has become an important component for integrated management of Fusarium tuber rot in caladium. The following studies were conducted to determine if there are any commercial cultivars that possess host plant resistance to Fusarium tuber rot (Goktepe et al., 2007).

\section{Identification of Optimal Temperatures to Screen Caladium Tubers for Host Plant Resistance}

Temperature has been recognized as an important factor in the development of diseases caused by Fusarium spp. Many Fusarium-induced diseases are favored by temperatures between 24 and $30^{\circ} \mathrm{C}$, probably due to the fact that this temperature range is optimum for mycelial growth of many Fusarium species. We examined the effects of temperature $\left(13,18,23,28\right.$, or $\left.33^{\circ} \mathrm{C}\right)$ on mycelial growth of $F$. solani on agar and the ability of $F$. solani isolates to cause tissue rot in caladium tubers. An isolate is a pure culture produced from an individual organism that has been recovered from the diseased tissue.

1. This document is ENH1081, one of a series of the Environmental Horticulture Department, Florida Cooperative Extension Service, Institute of Food and Agricultural Sciences, University of Florida. Original publication date October 22, 2007. Visit the EDIS Web Site at http://edis.ifas.ufl.edu.

2. Z. Deng, assistant professor; B.K. Harbaugh, professor, Gulf Coast Research and Education Center; N. A. Peres, assistant professor, Plant Pathology Department, Gulf Coast Research and Education Center, Wimauma, FL, Cooperative Extension Service, IFAS, University of Florida, Gainesville 32611.

The Institute of Food and Agricultural Sciences (IFAS) is an Equal Opportunity Institution authorized to provide research, educational information and other services only to individuals and institutions that function with non-discrimination with respect to race, creed, color, religion, age, disability, sex, sexual orientation, marital status, national origin, political opinions or affiliations. U.S. Department of Agriculture, Cooperative Extension Service, University of Florida, IFAS, Florida A. \& M. University Cooperative Extension Program, and Boards of County Commissioners Cooperating. Larry Arrington, Dean 
We determined that the optimal temperature to produce the greatest mycelial growth on agar would be at $30.5^{\circ} \mathrm{C}$ (Fig. 1). However, when tubers were inoculated with Fusarium, lower temperatures (13 or $18^{\circ} \mathrm{C}$ ) were more conducive to disease development, with the largest lesions observed at $13^{\circ} \mathrm{C}$ (Fig. 2). Tuber tissue texture changed sometimes when tubers were incubated at this temperature. Caladiums are tropical plants and their tubers are sensitive to temperatures below $15^{\circ} \mathrm{C}$. The tissue texture change might result from cold damage at $13^{\circ} \mathrm{C}$. Thus, $18^{\circ} \mathrm{C}$ appeared to be a safe temperature to allow rapid disease (tuber rot) progress while not causing cold injury to tubers.

When inoculated tubers were incubated at 25 to $30^{\circ} \mathrm{C}$, suberin formed around the inoculated sites and the infected tissue walled off from healthy tissue. Marousky and Raulston (1973) found that suberin formation in caladium was greatest at $32^{\circ} \mathrm{C}$ and was inhibited at 10 or $15^{\circ} \mathrm{C}$. Studies in other plants have indicated that suberin formation may be one of the major defense responses to pathogen infection. We suspect that at higher temperatures caladium tubers are able to seal off infected areas and slow down or stop penetration of $F$. solani hyphae, thus limiting tuber rot.

These results could also be applied to caladium storage. That is, since caladium tubers are more susceptible to Fusarium tuber rot at low temperatures, it is important to store and transport tubers at an appropriate temperature $\left(21^{\circ} \mathrm{C}\right)$.

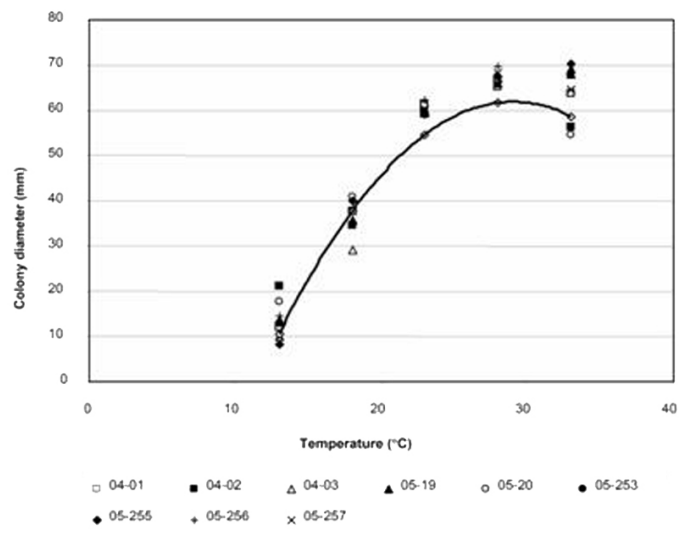

Figure 1. In vitro growth of nine isolates of Fusarium solani at five temperatures $\left(13,18,23,28\right.$, and $\left.33^{\circ} \mathrm{C}\right)$.

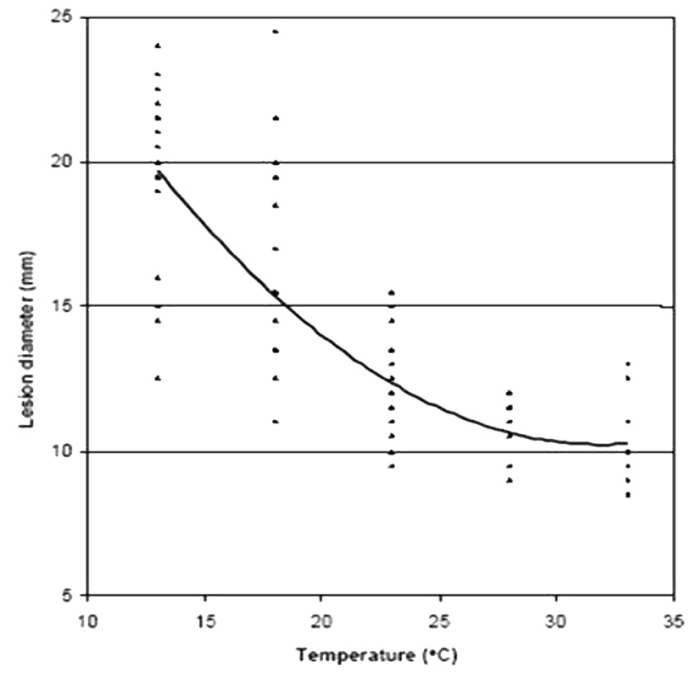

Figure 2. Lesion diameter ( $\mathrm{mm}$ ) of Fusarium tuber rot after inoculation with Fusarium solani isolate $05-20$ and incubation at five temperatures $\left(13,18,23,28\right.$, and $\left.33^{\circ} \mathrm{C}\right)$ for two weeks.

\section{Identification of Aggressive Fusarium Isolates for Evaluating Caladium Cultivars for Resistance to Fusarium Tuber Rot}

To determine if Fusarium isolates varied in their ability to rot caladium tubers and if cultivars responded differently to infection by different isolates, two cultivars were infected with nine Fusarium isolates. The nine isolates varied considerably in their aggressiveness, which was significantly influenced by the caladium cultivar (Table 1). For example, isolate 04-03 was the second most aggressive isolate on 'Frieda Hemple', but was among the least aggressive on 'Candidum'. Isolates 05-20 and 05-257 were highly aggressive on both cultivars, and they may be good candidates for future screening work.

Grower observations suggest that 'Frieda Hemple' is more susceptible to tuber rot than 'Candidum'. In our tests, the average diameter of rotted tissue ranged from 10.2 to $17.7 \mathrm{~mm}$ for 'Frieda Hemple', whereas on 'Candidum', the diameter ranged from 7.8 to $11.4 \mathrm{~mm}$. The differences in lesion diameter between 'Frieda Hemple' and 'Candidum' were significant for all isolates tested except 05-255. These results indicate that our testing procedures are applicable to grower situations and also confirm grower observations that cultivars differ in resistance to Fusarium tuber rot. 
Table 1. Diameter of rotted tuber tissue seven days after inoculation of caladium tubers with nine Fusarium solani isolates.

\begin{tabular}{|c|c|c|}
\hline \multirow[b]{2}{*}{ Isolate } & \multicolumn{2}{|c|}{$\begin{array}{l}\text { Lesion diameter ( } \mathrm{mm} \text { ) on two } \\
\text { cultivars }\end{array}$} \\
\hline & Frieda Hemple & Candidum \\
\hline 04-01 & 12.6 & 10 \\
\hline 04-02 & 12.5 & 10.3 \\
\hline $04-03$ & 14.9 & 8.3 \\
\hline $05-19$ & 11.3 & 9.2 \\
\hline $05-20$ & 17.7 & 11.4 \\
\hline $05-253$ & 10.2 & 7.8 \\
\hline $05-255$ & 11.2 & 9.9 \\
\hline $05-256$ & 10.3 & 8.7 \\
\hline $05-257$ & 13.5 & 10.4 \\
\hline
\end{tabular}

\section{Evaluating Commercial Cultivars for Resistance to Fusarium Tuber Rot Using Aggressive Isolates}

Seventeen major commercial caladium cultivars, 'Aaron', 'Candidum', 'Candidum Jr.', 'Carolyn Whorton', 'Fannie Munson', 'Florida Cardinal', 'Florida Sweetheart', 'Frieda Hemple', 'Gingerland', 'Miss Muffet', 'Postman Joyner', 'Red Flash', 'Red Frill', 'Rosebud', 'White Christmas', 'White Queen', and 'White Wing', were inoculated with three aggressive isolates; 04-03, 05-20, and 05-257. Cultivars were ranked from 1 to 17 within each isolate, with the rank of '1' assigned to the cultivar with the smallest lesion. The total rank sum (TRS) from all three isolates was then transformed to a normalized total rank by dividing the TRS by 51 , the highest possible TRS, and multiplied by 100 . Cultivars were placed into four categories based on the normalized total rank: resistant (with a normalized rank between $1 \%$ and $25 \%$ ), moderately resistant (25\% to $50 \%$ ), susceptible (50\% to $75 \%$ ), or highly susceptible ( $75 \%$ to $100 \%$ ).

Five cultivars ('Candidum', 'Rosebud', 'White Christmas', 'Florida Sweetheart', and 'Aaron') were placed in the "resistant" category with the normalized total rank ranging from $11.8 \%$ to $24.5 \%$ (Table 2). Two cultivars ('White Wing' and 'Red Flash') were placed in the moderately resistant group with the normalized total rank from $43.1 \%$ to $45.1 \%$. Six cultivars ('Candidum Jr.', 'White Queen', 'Red Frill', 'Florida Cardinal', 'Miss Muffet', and
'Postman Joyner') were placed in the susceptible category with the normalized total rank ranging from $52.9 \%$ to $70.6 \%$. Four cultivars were placed in the highly susceptible group ('Fannie Munson', 'Gingerland', 'Frieda Hemple', and 'Carolyn Whorton') with a normalized total rank from $82.4 \%$ to $100.0 \%$. The severity of the disease on 'Carolyn Whorton' was much greater than on all other cultivars, with most of its entire tuber surface infected by Fusarium (Fig. 3).

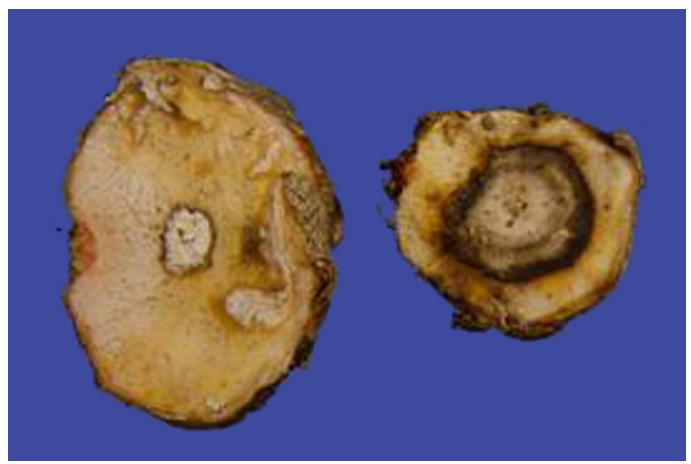

Figure 3. Fusarium tuber rot in tubers of 'Candidum' (left), a resistant cultivar, and 'Carolyn Whorton' (right), a highly susceptible cultivar. Tubers were cut in half, inoculated at the center of the cut surface with $F$. isolate 05-20, and incubated at $18^{\circ} \mathrm{C}$ for 2 weeks.

\section{References}

Goktepe, F., T. Seijo, Z. Deng, B.K. Harbaugh, N.A. Peres, and R.J. McGovern. 2007. Toward breeding for resistance to Fusarium tuber rot in caladium: inoculation technique and sources of resistance. HortScience 42:1135-1139.

Knauss, J.F. 1975. Description and control of Fusarium tuber rot of caladium. Plant Disease Report 59:975-979.

McGovern, R.J. 2004. Fighting Fusarium. Greenhouse Grower 22:146-150.

Marousky, F.J. and J.C. Raulston. 1973. Influence of temperature and duration of curing, storage, shipping and forcing periods on caladium growth. Proceedings of the Florida State Horticultural Society 86:363-368. 


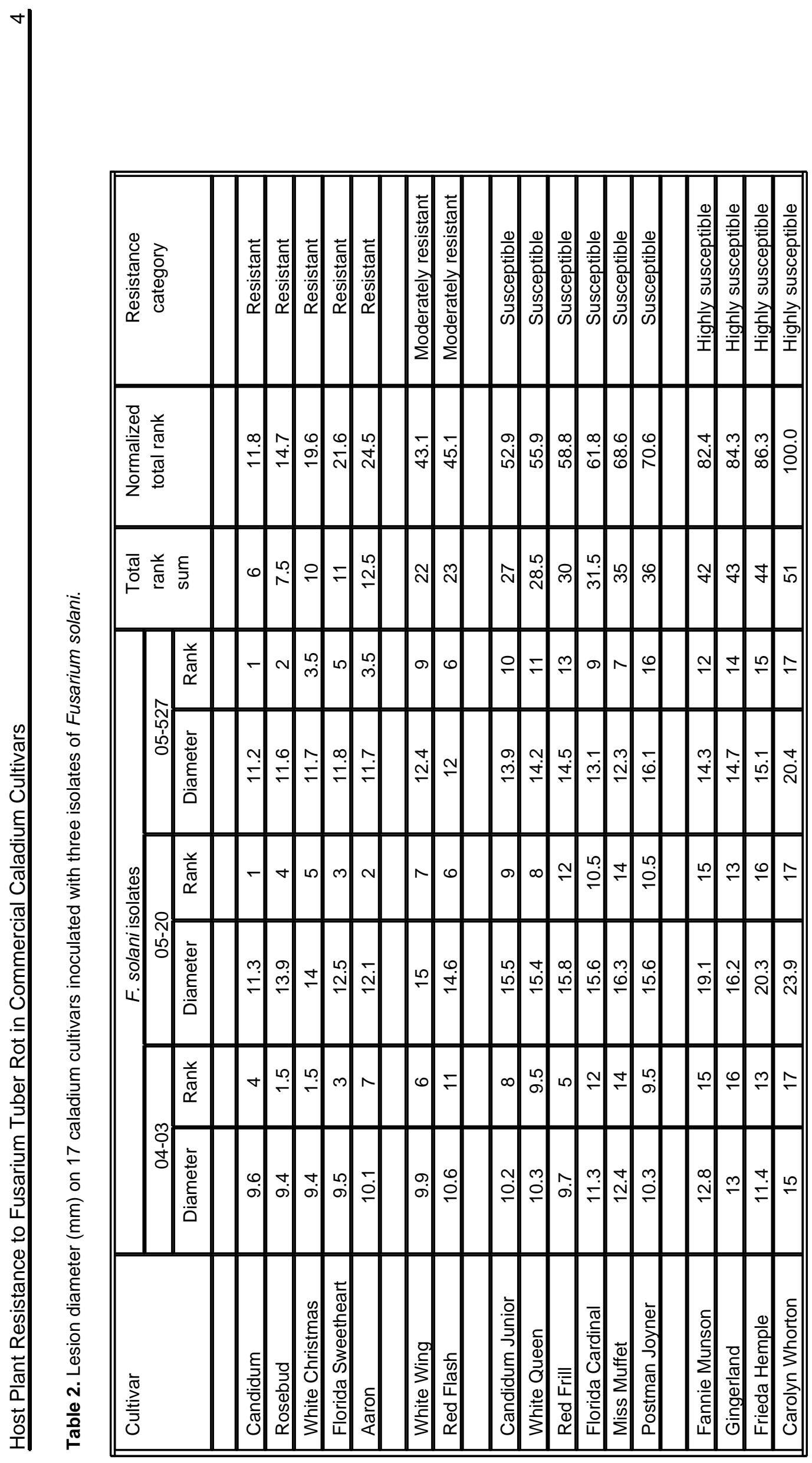

